\title{
Lysosomal cysteine proteases in the lung: role in protein processing and immunoregulation
}

\author{
F. Bühling*, N. Waldburg ${ }^{\#}$ A. Reisenauer*, A. Heimburg*, H. Golpon\#, T. Welte
}

Lysosomal cysteine proteases in the lung: role in protein processing and immunoregulation. F. Bühling, N. Waldburg, A. Reisenauer, A. Heimburg, H. Golpon, T. Welte. C) ERS Journals Ltd 2004.

ABSTRACT: Lysosomal cysteine proteases are a family comprising $>10$ enzymes. For many years it was believed that these enzymes catalyse protein breakdown unselectively, are highly redundant in their substrate specificity and are also expressed ubiquitously.

This view has changed dramatically since a number of new lysosomal cysteine proteases with restricted expression and outstanding enzymatic activity have been described. In addition, knockout mice and selective protease inhibitors have been used to characterise specific functions of single proteases.

In this review, some of these functions are discussed in relation to the lungs, especially the role of lysosomal cysteine proteases in matrix remodelling, immunoregulation and surfactant protein processing.

Eur Respir J 2004; 23: 620-628.
*Institute of Immunology, and ${ }^{*}$ Dept of Pneumology and Critical Care, Otto-vonGuericke-University Magdeburg, Magdeburg, Germany.

Correspondence: T. Welte, Dept of Pneumology and Critical Care, Otto-von-GuerickeUniversity Magdeburg, Leipziger-Str. 44, 39120 Magdeburg, Germany.

Fax: 4939167190466

E-mail: tobias.welte@medizin.uni-magdeburg.de

Keywords: Cathepsin, fibrosis, lung, protease, surfactant

Received: September 162003

Accepted after revision: January 62004
Under normal conditions, up to $50 \%$ of proteins are degraded within the lysosomal compartment [1]. This finding, along with the short intralysosomal half-life of proteins, demonstrates the high activity of lysosomal proteases [2]. Lysosomal proteolysis is limited by the activity of endoproteases that degrade internalised proteins into polypeptides. The terminal processing of these polypeptides is carried out by exopeptidases [3]. For many years it was believed that the lysosomal breakdown was a rather unselective process carried out by a number of highly redundant proteases that are expressed ubiquitously. However, this view has recently changed dramatically as knockout mice and selective protease inhibitors have been used to characterise specific functions of single proteases [4].

Proteases are classified, based on their catalytic mechanisms, into serin, aspartic, metallo, threonin and cysteine proteases. This overview focuses on cysteine proteases. In general, the term "protease" is used, which is synonymous with "peptidase", because it is commonly used in the medical literature. Proteases are enzymes that hydrolyse peptide bonds. They can be subdivided into exopeptidases, enzymes which act near a terminus of the polypeptide chain, and endopeptidases, which cleave internal peptide bonds. The old term "proteinase" carries the same meaning as "endopeptidase". The most comprehensive overview concerning the classification of proteases and their inhibitors has been compiled in the MEROPS database [5].

The term "cathepsin", which was introduced in 1920 [6], stands for "lysosomal proteolytic enzyme", regardless of the enzyme class. Therefore, in addition to cysteine proteases, this term also includes serine proteases (cathepsins A and G) and aspartic proteases (cathepsins D and E). Sequence homologies of the cysteine proteases (cathepsins B, C, H, L and S) indicate that these enzymes diverged early during eukaryotic evolution [7]. Some of the genes encoding novel enzymes, e.g. cathepsins $\mathrm{F}, \mathrm{K}, \mathrm{W}$ and $\mathrm{X}$, may be the result of relatively recent gene duplication events, as suggested by three gene pairs with common chromosomal localisation and high sequence homologies [8].

Cathepsins are synthesised as inactive preproenzymes and are glycosylated post-translationally. They are directed towards the lysosomal compartment using cellular mannose6-phosphate receptors. Some cells can secrete significant amounts of mature and procathepsins $[9,10]$.

Cathepsins are mostly monomeric proteins. Several threedimensional structures of cysteine proteases are available and demonstrate that enzymes of the papain family share a common fold $[4,11,12]$. The main structural features of a papain-like two-domain catalytic platform are depicted in figure 1 using a model of mature cathepsin $\mathrm{S}$; the active site is located at the interface between the two domains. Most cysteine proteases of the papain family are endopeptidases "by design". Exopeptidases, such as cathepsins B, C, H and X, are likely to have evolved from the endopeptidase template by addition of structural elements capable of interacting with the C- or N-terminus of a substrate [13-15].

The substrate-binding region of proteases is defined as an arrangement of binding pockets or subsites (S) for peptide substrate amino acids $(\mathrm{P})$ on both sites of the scissile bond. To date, seven such sites have been defined for papain-like cysteine proteases. The primary substrate specificity of cathepsins is defined by the $\mathrm{S}_{2}$ binding pocket $[16,17]$. However, recent studies support the importance of $\mathrm{S}_{3}$ and $\mathrm{S}_{4}$ sites for the determination of substrate specificity [18, 19]. Most lysosomal cysteine proteases accept hydrophobic amino acid residues, such as phenylalanine and leucine, at the $S_{2}$ position. In contrast to other cathepsins, cathepsin B also accepts arginine in this position.

The exceptional enzymatic activity of cathepsin $\mathrm{K}$ is based on its ability to cleave protein substrates with proline residues 


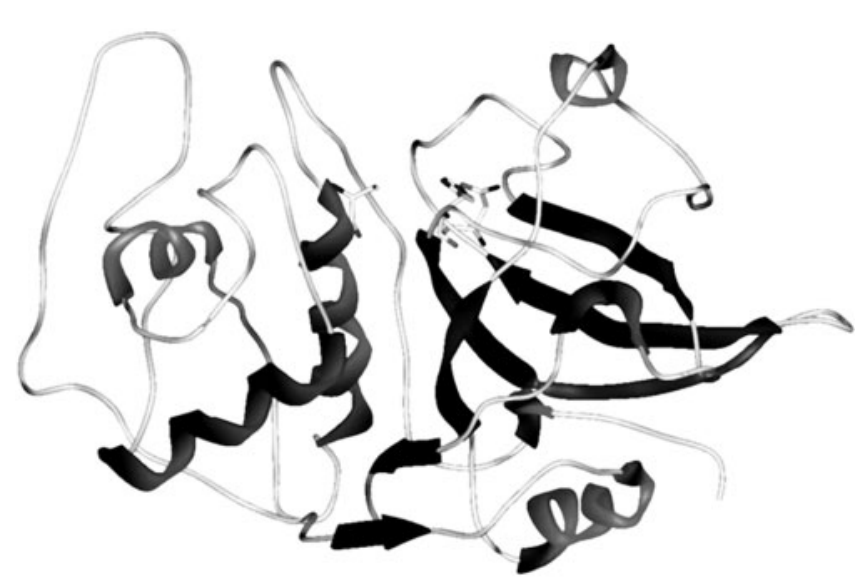

Fig. 1.-Secondary structure representation of mature cathepsin S. Catalytic residues are highlighted as capped sticks. Figure kindly provided by W. Brandt, Martin-Luther-University Halle, Halle, Germany.

in the $\mathrm{P}_{2}$ position [20]. Thus, cathepsin $\mathrm{K}$ cleaves collagen I and II fibres at different sites in both the telopeptide and the helical regions [21]. In contrast, cathepsin L catalyses the hydrolysis of collagen in the telopeptide region only, whereas matrix metalloproteases (MMPs) mediate the cleavage at a single site within the helical region. Before the discovery of cathepsin K, it was suggested that collaboration of different proteases is a precondition for collagen degradation. It was thought that cathepsin L-like proteases were involved in destabilising the collagen fibres and making them accessible for further breakdown by MMPs [22]. However, now it is clear that cathepsin $\mathrm{K}$ is the first mammalian protease to be described that is capable of independent collagen breakdown. Similar activities have previously only been described for bacterial proteases. The importance of cathepsin $\mathrm{K}$ in matrix metabolism in vivo is supported by the finding that inactivating mutations in the cathepsin $\mathrm{K}$ gene render osteoclasts, which express large amounts of cathepsin $\mathrm{K}$, dysfunctional and lead to the hereditary disease pycnodysostosis [23]. The functional relevance of cathepsin $\mathrm{K}$ at other expression sites is less well understood.

A number of studies have investigated elastin degradation by lysosomal cysteine proteases and showed that cathepsin $\mathrm{K}$ is one of the most potent elastases described to date [24]. In addition, the elastinolytic activities of cathepsins $\mathrm{L}$ and $\mathrm{S}$ are, at optimal $\mathrm{pH}$, higher than the activities of neutrophil elastase and metalloelastase [25]. Both the collagenolytic and elasinolytic activities of cathepsins appear to be important for matrix remodelling in the lungs.

\section{Regulation of enzymatic activity}

The activity, and thus the functional importance of cathepsins, is regulated at different levels (fig. 2). Initially, it was believed that cathepsins were "housekeeping" proteins and therefore ubiquitously expressed. This view has evolved as cathepsins with distinct expression patterns have been described. Examples include: cathepsin K, which is found in large amounts in osteoclasts, activated macrophages and some epithelial cell-s [26-30]; cathepsin S, found in antigenpresenting cells $[31,32]$; and cathepsin $\mathrm{W}$, which has been detected in cytotoxic lymphocytes [33-35]. The same view is also reflected in the lungs (fig. 3), where some cathepsins are expressed more or less ubiquitously, for example cathepsins B, H and L, whereas others are expressed either

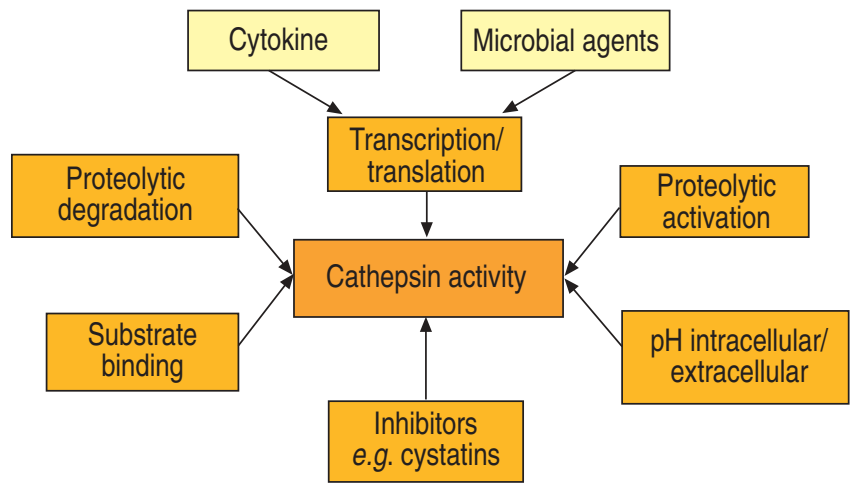

Fig. 2.-Regulation of enzymatic cathepsin activity.

in macrophages (cathepsin S) or in bronchial epithelial cells (cathepsin K). Of note are type II pneumocytes, which express significant amounts of cathepsin $\mathrm{H}$, but low levels of the other cathepsins (table 1) [28, 36, 37].

Furthermore, cathepsin expression and activity are regulated by cytokines and microbial agents. Interferon (IFN)- $\gamma$ and interleukin (IL)-6 stimulate expression of cathepsins B and L, whereas transforming growth factor- $\beta_{1}$ and IL-10 inhibit enzymatic activity in most cells [38-41]. Stimulation of macrophages by bacterial lipopolysaccharide also leads to increased cathepsin expression [42, 43].

The majority of enzymes, including cathepsins, are synthesised as inactive precursors. In addition to being selective competitive inhibitors of the parent enzyme, the proregions appear to be important for the correct folding of the newly synthesised polypeptide chain and for stabilising the protein against denaturation caused by neutral or slightly alkaline $\mathrm{pH}$ [44]. The removal of propeptides is a precondition for enzymatic activation [13, 45, 46-49]. The enzymatic activation of cathepsins is achieved by other cathepsins or by autocatalysis. Exopeptidases, such as cathepsin C or X, are activated exclusively by other lysosomal endoproteases, and proteolytic activation depends on $\mathrm{pH}$ and the concentration of glucosaminoglycans $[15,50,51]$.

Furthermore, cathepsins are controlled by proteolytic degradation and inactivation of the proteases themselves. For example, cathepsin L is inactivated by cathepsin S [52] and the inhibition of lysosomal cysteine proteases leads to delayed cathepsin D processing [53].

Cathepsins have an acidic $\mathrm{pH}$ optimum. In general, environments with neutral or alkaline $\mathrm{pH}$ lead to inactivation of cathepsins. However, the rate of inactivation varies among the different members of the protease family. Cathepsin $\mathrm{L}$ is inactivated rapidly, whereas cathepsin $\mathrm{S}$ retains most of its activity for $>1 \mathrm{~h}$. Cathepsins $\mathrm{K}$ and $\mathrm{V}$ have an intermediate sensitivity to increasing $\mathrm{pH}[27,54,55]$. In addition, recent investigations have shown that cathepsins are stabilised after formation of complexes with potential substrates. This is illustrated by the findings that inactivation of cathepsin $\mathrm{L}$ at neutral $\mathrm{pH}$ is prevented by binding of the $\mathrm{p} 41$ protein and that cathepsin B is stabilised extracellularly by high protein concentrations $[56,57]$.

Finally, because of the exceptional proteolytic activity and the high concentration of cathepsins, up to $1 \mathrm{mM}$ in lysosomes, their activity is controlled by a network of endogenous inhibitors. The activity is mostly controlled by cystatins, which are expressed intracellularly (cystatins A and B) or extracellularly (cystatins C, D, and F) [58]. Other endogenous cathepsin inhibitors include kininogens, serpins and $\alpha_{2^{-}}$ macroglobulin [59-61]. 

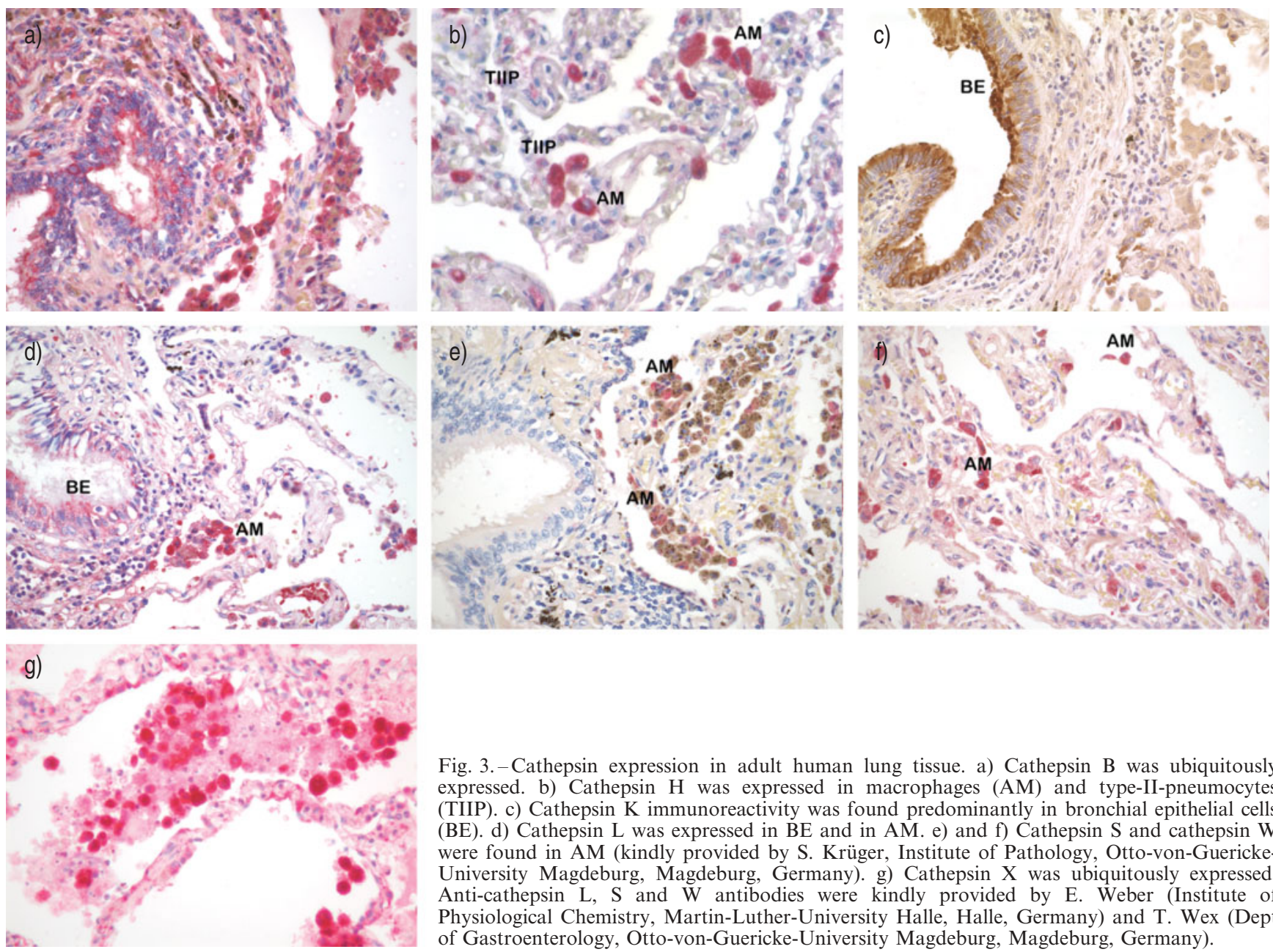

Fig. 3.-Cathepsin expression in adult human lung tissue. a) Cathepsin B was ubiquitously expressed. b) Cathepsin $\mathrm{H}$ was expressed in macrophages (AM) and type-II-pneumocytes (TIIP). c) Cathepsin K immunoreactivity was found predominantly in bronchial epithelial cells (BE). d) Cathepsin L was expressed in BE and in AM. e) and f) Cathepsin S and cathepsin W were found in AM (kindly provided by S. Krüger, Institute of Pathology, Otto-von-GuerickeUniversity Magdeburg, Magdeburg, Germany). g) Cathepsin X was ubiquitously expressed. Anti-cathepsin L, S and W antibodies were kindly provided by E. Weber (Institute of Physiological Chemistry, Martin-Luther-University Halle, Halle, Germany) and T. Wex (Dept of Gastroenterology, Otto-von-Guericke-University Magdeburg, Magdeburg, Germany).

\section{In vivo functions of cathepsins}

\section{Cathepsin knockout mice}

During the last $8 \mathrm{yrs}$ the phenotypes of seven different cathepsin knockout mice have been described. In addition to the aspartic proteases, cathepsins D and E, the genes of the lysosmal cysteine proteases of the papain family, cathepsins C, B, L, K and S, have been inactivated [62-69].

In one study, cathepsin B knockout mice displayed no obvious phenotype [70], but detailed analyses of thyroid function in cathepsin B-deficient mice revealed defects in thyroglobulin processing [71]. In addition, after caerulein challenge, these mice were less susceptible to the induction of acute pancreatitis; pancreatic damage was $50 \%$ lower in cathepsin B-deficient animals compared with control animals [63]. Furthermore, recent investigations have demonstrated that cathepsin B is involved in the induction of hepatocyte apoptosis; genetic or pharmacological inhibition of cathepsin $\mathrm{B}$ reduced the amount of apoptotic hepatocytes, and thus inflammation and fibrosis after bile duct ligation [72].

Cathepsin C (dipeptidyl peptidase I) knockout mice have displayed severe defects in the induction of target cell apoptosis by cytotoxic T-cells. As cathepsin C plays an essential role in the in vivo processing and activation of granzymes $\mathrm{A}$ and $\mathrm{B}$, which are required for cytotoxic lymphocyte granule-mediated apoptosis, these defects are comparable with those detected in perforin- or granzyme A-/ B-deficient cytotoxic lymphocytes [73]. Furthermore, defects in cathepsin $\mathrm{C}$ activity may have severe consequences for antiviral protection and the removal of tumour cells. More recently, it was shown that cathepsin $\mathrm{C}$ knockout mice are protected against acute arthritis; this protective function was

Table 1.-Immunoreactivity in lung tissue and enzymatic activity of cathepsins

\begin{tabular}{|c|c|c|}
\hline Enzyme & $\begin{array}{l}\text { Expression pattern } \\
\text { in lung tissue } \\
\text { (immunhistochemistry) }\end{array}$ & Proteolytic activity \\
\hline \multirow[t]{2}{*}{ Cathepsin B } & Ubiquitous & Carboxypeptidase \\
\hline & $\begin{array}{l}\text { Strongly in bronchial } \\
\text { epithelial cells and } \\
\text { macrophages }\end{array}$ & Endoprotease \\
\hline \multirow[t]{2}{*}{ Cathepsin H } & Ubiquitous & Aminopeptidase \\
\hline & $\begin{array}{l}\text { Strongly in macrophages } \\
\text { and type-II-epithelial cells }\end{array}$ & Endoprotease \\
\hline Cathepsin $\mathrm{K}$ & $\begin{array}{l}\text { Bronchial epithelial cells } \\
\text { Macrophages (?) }\end{array}$ & Endoprotease \\
\hline Cathepsin L & $\begin{array}{l}\text { Ubiquitous } \\
\text { Strongly in bronchial } \\
\text { epithelial cells and } \\
\text { macrophages }\end{array}$ & Endoprotease \\
\hline Cathepsin S & Macrophages & Endoprotease \\
\hline Cathepsin X & $\begin{array}{l}\text { Ubiquitous } \\
\text { Strongly in macrophages }\end{array}$ & Carboxypeptidase \\
\hline Cathepsin W & $\begin{array}{l}\text { Strongly in macrophages } \\
\text { Some lymphocytes }\end{array}$ & ? \\
\hline
\end{tabular}


linked to defects in the proteolytic activation of cathepsin $G$, neutrophil elastase and proteinase 3 [62]. The question of whether this incomplete activation, especially that of leukocyte elastase, is associated with defects in the antibacterial response remains to be resolved [74, 75]. In addition, cathepsin $\mathrm{C}$ activates mast cell chymases in vivo [76] and is therefore involved in the regulation of allergic reactions.

Cathepsin K-deficient mice display an osteopetrotic phenotype, with excessive trabeculation of the bone marrow space. This phenotype could be related to alterations in the function of osteoclasts [67]. Accordingly, histomorphometric analyses of cathepsin K-overexpressing mice revealed significantly decreased trabecular bone volume and acceleration of bone turnover [77]. However, the phenotype displayed by cathepsin $\mathrm{K}$ knockout mice is mild compared with the human cathepsin $\mathrm{K}$ deficiency, pycnodysostosis. Pycnodysostosis is associated with severe skeletal dysplasia, including short stature and dysplasia of cranial bones. Therefore, it was suggested that there is only a partial functional overlap in the functions of human and mouse cathepsin $\mathrm{K}$.

The most prominent phenotype was found after inactivation of cathepsin L, which underlines the well-known high endoproteolytic potential of this ubiquitous protease. Cathepsin L gene (CTSL)-deficient mice develop periodic hair loss and epidermal hyperplasia, acanthosis and hyperkeratosis. The hair loss is due to alterations in hair follicle morphogenesis and cycling, dilatation of hair follicle canals, and disturbed club hair formation. Hyperproliferation of hair follicle epithelial cells and basal epidermal keratinocytes are the primary characteristics underlying the mutant phenotype [64]. The phenotype of CTSL-deficient mice is reminiscent of the spontaneous mouse mutants furless and nackt [78, 79], which also involve the cathepsin L gene. Recently, it has been found that older CTSL knockout mice develop a dilated cardiomyopathy associated with interstitial fibrosis in the myocardium [80]. In addition to these findings, recent publications have documented the function of CTSL in prohormone processing. In thyroid and neuroendocrine cells of cathepsin L-deficient mice there was a distinct accumulation of the prohormones thyroglobulin and proenkephalin, respectively $[71,81]$.

In vivo, the crucial role of cathepsins in immunoregulation was first demonstrated in cathepsin L knockout mice [82].

\section{Cathepsins in antigen presentation}

Extracellular antigens, which are taken up by professional and nonprofessional antigen-presenting cells, are mostly degraded in the endosomal/lysosomal compartment. The resulting peptides are displayed on the cell surface after formation of major histocompatability complex (MHC) class II-peptide complexes. MHC class II $\alpha \beta$ heterodimers are synthesised in the endoplasmic reticulum. During the early stages of biosynthesis, the $\alpha \beta$ heterodimers associate with a type II membrane protein, the invariant chain (Ii), to form a nonameric complex of $\alpha \beta \mathrm{Ii}$. Ii associates with class II molecules via direct interaction of its luminal domain with the antigen-binding groove of class II molecules. The $\alpha \beta$ Ii complex traverses the Golgi apparatus and is delivered to the endosomal/lysosomal compartment were Ii is degraded and liberated from the $\alpha \beta \mathrm{Ii}$ complex. This allows the class II molecules to encounter and bind the antigenic peptides. Proteolysis participates in generation of class II-peptide complexes at two critical points: proteolytic degradation of $\mathrm{Ii}$, which is a prerequisite of peptide loading; and generation of the antigenic peptides from larger proteins.

Cathepsin L knockout mice show reduced positive selection of CD4+ T-cells, which is caused in part by a block in late Ii processing steps, and, therefore, decreased loading and presentation of class II complexes with self peptides [82]. Additionally, evidence was found in cortical thymic epithelial cells that lack of cathepsin L activity shifts the pattern of self antigens presented by the class II complexes [83]. Therefore, T-cells that have been positively selected against peptides presented by cortical thymic epithelial cells fail to pass the negative selection against the peptides presented by dendritic cells. This is because the latter employ cathepsin $\mathrm{S}$ for antigen processing and therefore present the common pattern of self antigens. The finding that different antigen-presenting cells use different cathepsins for processing of Ii and antigens was later supported by data derived from cathepsin $\mathrm{S}$ knockout mice, indicating that cathepsin $\mathrm{S}$ is a major Ii-processing enzyme in B-cells and dendritic cells [66]. The finding that mouse macrophages are using predominantly cathepsin $\mathrm{F}$ for Ii processing and class II peptide loading is not yet proven in knockout mice [84].

The immunoregulatory function of defined cathepsins in mice is not necessarily identical to the function of similar enzymes in humans. For example, it was suggested that cathepsin V replaces cathepsin L in human cortical thymic epithelial cells [55]. Cathepsin V is highly expressed in human thymus, testis and corneal epithelium [55, 85]. However, the mouse genome does not contain a cathepsin $\mathrm{V}$ gene. In addition, by exploring human epithelial cells overexpressing the proteins of the MHC class II complex, it was shown that only human cathepsin $\mathrm{S}$, and not human cathepsin $\mathrm{L}$, was able to process Ii and thus to play a pivotal role in antigen presentation by epithelial cells [32].

The suppression of cathepsin F, but not of cathepsin S, in the lungs prevents eosinophilia and immunoglobulin $\mathrm{E}$ response after ovalbumin challenge [84]. In mice, alveolar macrophages express large amounts of cathepsin F, which suggests a pivotal role for these cells in immunoregulation.

Further studies should characterise the expression and function of additional cysteine proteases, e.g. cathepsins B, K and $\mathrm{L}$, in antigen-presenting cells of the lungs and also explore in more detail the effects of selective inhibition of these enzymes on the development of allergic reactions.

\section{Cysteine proteases in matrix remodelling of the lung}

The extracellular matrix (ECM) of most tissues contains a complex mixture of collagens, proteoglycans and elastin. The pulmonary ECM is subjected to a continuous turnover of $>10 \%$ of total ECM per day [86]. For complete degradation, the concerted action of several hydrolases, both inside and outside cells, is necessary. Proteolytic processing is needed for maturation and controlled deposition of ECM. Extracellularly, collagens are degraded by collagenases, gelatinases and stromelysin. These proteases cleave collagen helices at a defined site, leaving $2 / 3$ and $1 / 3$ fragments to be phagocytosed by cells such as fibroblasts and macrophages [22]. Within these cells, the matrix-containing phagosomes fuse with lysosomes in which cathepsins complete the degradation.

In addition to intracellular degradation of collagens, cathepsins can also degrade matrix proteins extracellularly. Cells found to release cathepsins include macrophages (cathepsins B, K, L and S) [87], mast cells (cathepsins C and L) [88], smooth muscle cells (cathepsins $\mathrm{K}$ and $\mathrm{S}$ ) [89], fibroblasts (cathepsins B and K) and tumour cells (cathepsins B, L and S) [90-92]. Most cathepsins have optimal activity at an acidic $\mathrm{pH}$. Some cathepsins, e.g. cathepsin L, lose their activity quickly after incubation at a neutral $\mathrm{pH}$. However, several recently described cathepsins maintain their enzymatic 
activity even after incubation at neutral $\mathrm{pH}$ and thus can degrade matrix proteins under physiological conditions. Cathepsins $\mathrm{C}$ and $\mathrm{S}$ have been found to have the highest $\mathrm{pH}$ stability [54, 88], while cathepsins $\mathrm{K}$ and $\mathrm{V}$ display intermediate $\mathrm{pH}$ stability $[27,55]$. In vitro investigations have shown that cathepsin $\mathrm{K}$ can degrade fibril proteins at neutral $\mathrm{pH}$ [93].

Furthermore, cells releasing cathepsins might promote extracellular proteolysis by direct acidification of the pericellular space. For example, osteoclasts release their lysosomal contents into the resorption lacunae [94]. In addition, PUNTURIERI et al. [87] have reported the acidification of the pericellular environment by macrophages. In vitro, monocytederived macrophages adhere tightly to elastin particles and form a sequestrated environment, which is then acidified by using a vacuolar type $\mathrm{H}^{+}$-ATPase to pump protons from the cytoplasmic to the extracellular space. Similar mechanisms may be involved in matrix remodelling by lung macrophages and may also contribute to the pathogenesis of granulomatous lung diseases, which are characterised by the appearance of multinucleated giant cells (MGC). Recently it was shown that MGC express and release large amounts of cathepsin $\mathrm{K}$ $[29,93,95]$. Conversely, it was shown that MGC can enclose foreign materials, micro-organisms or other extracellular components. Therefore, it is likely that $\mathrm{MGC}$ are also generating an acidified micro-environment and use cathepsins for extracellular degradation.

Chronic obstructive lung disease (COPD) is a generic term covering several clinical entities, including emphysema and chronic bronchitis. Emphysema is characterised by abnormal permanent enlargement of the air space distal to the terminal bronchiole accompanied by destruction of alveolar walls. It has been shown recently that lymphocytes and activated macrophages are involved in the regulation of COPD and the development of emphysema.

Initiated by the finding that intratracheal instillation of cathepsin B in an animal model caused a phenotype that resembles human emphysema [96], a number of studies were performed to characterise the putative role of lysosomal cysteine proteases like cathepsin B and L in the development of emphysema [97, 98]. These proteases were found to be strongly expressed in activated macrophages. It was shown that the concentration of cathepsin L was significantly increased in the bronchoalveolar lavage fluid of smokers with emphysema [36, 99].

Based on the hypothesis that the cytokine-regulated activation of macrophages leads to cathepsin release, WANG et al. [100] and ZHENG et al. [101] established transgenic murine models employing the inducible expression of cytokines along the alveolar surface; the overproduction of IL-13 or IFN- $\gamma$ caused a phenotype that mirrors human COPD, with emphysema, enlarged lungs and enhanced pulmonary compliance. These changes were accompanied by increased expression of MMPs and cathepsins in the lungs. When mice were given the cysteine protease inhibitor E64, they showed markedly attenuated emphysematous changes, implying that cysteine proteases are important in the development of cytokine-induced emphysema [101]. Further investigations should determine whether induction of cytokines on a cathepsin-deficient background attenuates the development of emphysema.

A further question to be addressed is whether cathepsins influence the development of lung fibrosis. The current authors have previously shown that activated pulmonary fibroblasts express large amounts of cathepsin $\mathrm{K}$. The cathepsin $\mathrm{K}$ expression in fibroblasts derived from patients with interstitial pulmonary fibrosis or bronchiolitis obliterans obstructive pneumonia was increased compared with fibroblasts from normal lung tissues. Using the model of bleomycin-induced lung fibrosis, an induction of cathepsin expression was detected after bleomycin challenge. Using cathepsin $\mathrm{K}$ knockout mice, increased lung fibrosis was found after bleomycin challenge. From these results, the authors concluded that cathepsin $\mathrm{K}$ may be involved in matrix degradation and thus may counteract the increased matrix deposition responsible for the development of lung fibrosis.

Lung cancer cells can secrete cathepsins $\mathrm{L}$ and $\mathrm{B}$ in vitro $[90,92]$ and anti-cathepsin $\mathrm{L}$ antibodies protect against the formation of solid tumours by implanted myeloma cells in vivo [102]. Therefore, it was suggested that cathepsins may play a critical role in tumour invasion and progression. In addition, it was shown in a number of in vitro models using cells of different origins that inhibition of cathepsin B or cathepsin $\mathrm{L}$ by specific inhibitors, or suppression of protease expression using antisense technologies, decreases the invasion of tumour cells into the ECM [103-105]. Conversely, the present authors' recent investigations indicate that cathepsin $\mathrm{K}$ does not play a role in the progression of lung tumours [106]. It was found that the expression of cathepsin $\mathrm{K}$ is downregulated in lung tumours on a per cell basis when compared with differentiated bronchial epithelial cells. Therefore, future studies exploring tumour models in cathepsin knockout mice should provide more definite answers to the question of which cathepsins are really involved in the progression of lung tumours.

\section{Processing of surfactant proteins by cysteine proteases}

Pulmonary surfactant is a mixture of lipids and specific proteins, which is secreted into the alveolar space by the typeII pneumocytes. Its main function is the reduction of surface tension at the air-liquid interface, thus preventing alveolar collapse at end-expiration. The surfactant proteins (SP)-B and -C play an essential role in the metabolism and dynamics of the pulmonary surfactant lipids (reviewed in [107]). Hereditary SP-B deficiency in infants or mice leads to respiratory failure at birth [108-111]. Mutations in the human SP-C gene are associated with interstitial lung disease [112, 113]. In a defined genetic background, SP-C knockout mice develop chronic pneumonitis and emphysema [114]. In addition, both hereditary alveolar proteinosis in babies without detectable mutations in the SP-B or the SP-C gene and acquired pulmonary alveolar proteinosis in children and adults are characterised by intra-alveolar accumulation of mature surfactant proteins and abnormal SP-B precursors. SP-B precursors only are detected in babies with congenital surfactant defects characterised by the absence of lamellar bodies in type-II pneumocytes (F. Brasch, Institute of Pathology, University Hospital "Bergmannsheil", Bochum, Germany, personal communication). Therefore, insufficient processing of proSP-B or proSP-C due to a lack or dysfunction of one or more proteases involved in surfactant protein processing might be another, yet undiscovered, cause of surfactant dysfunction in pulmonary diseases in babies, children and adults.

The hydrophobic surfactant proteins SP-B and -C are transported via the endoplasmic reticulum, the Golgi system and multivesicular bodies from their site of synthesis at the ribosomes to the lamellar bodies. On this route, the primary translation products, proproteins (proSP-B, proSP-C) with molecular masses of 42 and $21 \mathrm{kDa}$, undergo extensive $\mathrm{C}$ - and $\mathrm{N}$-terminal processing in multivesicular bodies and lamellar bodies [115-118]. Although various processing steps have been described so far $[119,120]$, nothing is known about the identity of the proteases involved. As a result of the acidic $\mathrm{pH}$ in multivesicular and lamellar bodies, cathepsins are potential 


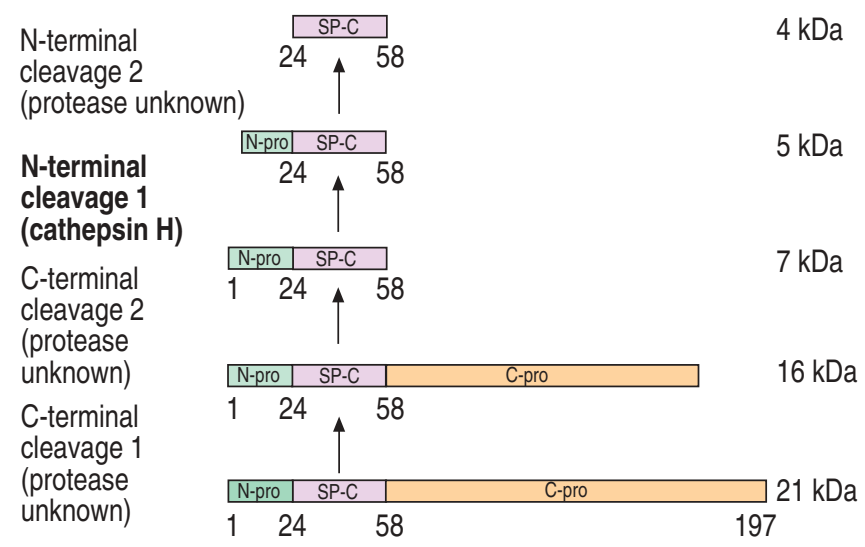

Fig. 4.-Processing of surfactant protein (SP)-C precursor by cathepsin $\mathrm{H}$.

candidates for involvement in surfactant protein processing. It has been shown in vitro that cathepsin $\mathrm{D}$ or a "cathepsin D-like protease" catalyses the post-translational processing of the hydrophobic proSP-B [121], but cathepsin D itself was not detected in type-II pneumocytes and no specific activity was found in isolated lamellar bodies [122, 123]. In contrast, the lysosomal protease cathepsin $\mathrm{H}$ was localised in lamellar bodies of type-II pneumocytes of the rat lung [124]. Immunoelectronmicroscopic investigations have shown that cathepsin $\mathrm{H}$, proSP-B and proSP-C are colocalised in multivesicular and lamellar bodies of type-II pneumocytes. Isolated rat lamellar bodies were also shown to express enzymatic cathepsin $\mathrm{H}$ activity. In human foetal type-II pneumocytes, the expression and enzymatic cathepsin $\mathrm{H}$ activity was upregulated during in vitro differentiation in parallel with surfactant protein secretion. Incubation of differentiated type-II pneumocytes with E64, a potent inhibitor of cysteine proteases, interrupts SP-B processing and leads to additional features of SP-B deficiency, including abnormal SP-C processing and aberrant lamellar bodies [125].

The SP-C processing by cathepsin $\mathrm{H}$ was investigated in more detail in vitro. It was suggested that cathepsin $\mathrm{H}$ is involved in the N-terminal processing of proSP-C in electron dense multivesicular bodies (fig. 4) [126]. It should to be pointed out that, in these studies, the processing of proSP-C by cathepsin $\mathrm{H}$ alone did not result in the mature surfactant proteins. Therefore, additional enzymes also seem to be involved in this complex processing cascade. Studies using knockout mice for different combinations of lysosomal proteases should be initiated to characterise other enzymes involved in surfactant protein processing.

\section{Conclusion}

Using molecular biological methods, such as knockout mice and antisense approaches, a number of specific functions of cathepsins have been highlighted during recent years. Without doubt, it has been shown that cathepsins play a crucial role in matrix remodelling, immunoregulation and surfactant protein processing. On-going research with animal models and the detailed investigation of human lung diseases will clarify their role in the pathogenesis of different lung diseases.

\section{References}

1. Ahlberg J, Berkenstam A, Henell F, Glaumann H. Degradation of short and long lived proteins in isolated rat liver lysosomes. Effects of $\mathrm{pH}$, temperature, and proteolytic inhibitors. J Biol Chem 1985; 260: 5847-5854.

2. Mortimore GE, Lardeux BR, Adams CE. Regulation of microautophagy and basal protein turnover in rat liver. Effects of short-term starvation. J Biol Chem 1988; 263: 2506-2512.

3. Bohley P, Seglen PO. Proteases and proteolysis in the lysosome. Experientia 1992; 48: 151-157.

4. Bühling F, Fengler A, Brandt W, Welte T, Ansorge S, Nagler DK. Review: novel cysteine proteases of the papain family. Adv Exp Med Biol 2000; 477: 241-254.

5. MEROPS - the peptidase database. http://merops.sanger. ac.uk. Date last updated: December 22, 2003. Date last viewed: January 25, 2004.

6. Willstätter R, Bamann E. Proteases in the gastric mucosa [Über die Proteasen der Magenschleinhaut]. Hoppe-Seyler's Z Physiol Chem 1929; 180: 127-143.

7. Berti PJ, Storer AC. Alignment/phylogeny of the papain superfamily of cysteine proteases. J Mol Biol 1995; 246: 273283.

8. Wex T, Levy B, Wex H, Bromme D. Human cathepsins F and W: a new subgroup of cathepsins. Biochem Biophys Res Commun 1999; 259: 401-407.

9. McCormick D. Secretion of cathepsin B by human gliomas in vitro. Neuropathol Appl Neurobiol 1993; 19: 146-151.

10. Felbor U, Dreier L, Bryant RA, Ploegh HL, Olsen BR, Mothes W. Secreted cathepsin L generates endostatin from collagen XVIII. EMBO J 2000; 19: 1187-1194.

11. Turk V, Turk B, Turk D. Lysosomal cysteine proteases: facts and opportunities. EMBO J 2001; 20: 4629-4633.

12. Cygler M, Mort JS. Proregion structure of members of the papain superfamily. Mode of inhibition of enzymatic activity. Biochimie 1997; 79: 645-652.

13. Turk D, Podobnik M, Kuhelj R, Dolinar M, Turk V. Crystal structures of human procathepsin $\mathrm{B}$ at 3.2 and 3.3 Angstroms resolution reveal an interaction motif between a papain-like cysteine protease and its propeptide. FEBS Lett 1996; 384: 211-214.

14. Guncar G, Podobnik M, Pungercar J, Strukelj B, Turk V, Turk D. Crystal structure of porcine cathepsin H determined at $2.1 \mathrm{~A}$ resolution: location of the mini-chain $\mathrm{C}$-terminal carboxyl group defines cathepsin $\mathrm{H}$ aminopeptidase function. Structure 1998; 6: 51-61.

15. Nagler DK, Zhang R, Tam W, Sulea T, Purisima EO, Menard R. Human cathepsin X: a cysteine protease with unique carboxypeptidase activity. Biochemistry 1999; 38: $12648-12654$.

16. Wang B, Shi GP, Yao PM, Li Z, Chapman HA, Bromme D. Human cathepsin F - molecular cloning, functional expression, tissue localization, and enzymatic characterization. J Biol Chem 1998; 273: 32000-32008.

17. Schechter I, Berger A. On the active site of proteases. 3. Mapping the active site of papain; specific peptide inhibitors of papain. Biochem Biophys Res Commun 1968; 32: 898-902.

18. Alves MF, Puzer L, Cotrin SS, et al. S3 to S3' subsite specificity of recombinant human cathepsin $\mathrm{K}$ and development of selective internally quenched fluorescent substrates. Biochem J 2003; 373: 986.

19. Lecaille F, Choe Y, Brandt W, Li Z, Craik CS, Bromme D. Selective inhibition of the collagenolytic activity of human cathepsin $\mathrm{K}$ by altering its $\mathrm{S} 2$ subsite specificity. Biochemistry 2002; 41: 8447-8454.

20. Aibe K, Yazawa H, Abe K, et al. Substrate specificity of recombinant osteoclast-specific cathepsin $\mathrm{K}$ from rabbits. Biol Pharm Bull 1996; 19: 1026-1031.

21. Garnero P, Borel O, Byrjalsen I, et al. The collagenolytic activity of cathepsin $\mathrm{K}$ is unique among mammalian proteinases. J Biol Chem 1998; 273: 32347-32352.

22. Everts V, van der Zee E, Creemers L, Beertsen W. Phagocytosis and intracellular digestion of collagen, its role in turnover and remodelling. Histochem J 1996; 28: 229-245.

23. Gelb BD, Shi GP, Chapman HA, Desnick RJ. Pycnodysostosis, 
a lysosomal disease caused by cathepsin K deficiency. Science 1996; 273: 1236-1238.

24. Chapman HA, Riese RJ, Shi GP. Emerging roles for cysteine proteases in human biology. Annu Rev Physiol 1997; 59: 6388.

25. Chapman HA, Munger JS, Shi GP. The role of thiol proteases in tissue injury and remodeling. Am J Respir Crit Care Med 1994; 150: 155-159.

26. Bromme D, Okamoto K. Human cathepsin O2, a novel cysteine protease highly expressed in osteoclastomas and ovary molecular cloning, sequencing and tissue distribution. Biol Chem Hoppe Seyler 1995; 376: 379-384

27. Bromme D, Okamoto K, Wang BB, Biroc S. Human cathepsin $\mathrm{O} 2$, a matrix protein-degrading cysteine protease expressed in osteoclasts. Functional expression of human cathepsin $\mathrm{O} 2$ in Spodoptera frugiperda and characterization of the enzyme. J Biol Chem 1996; 271: 2126-2132.

28. Bühling F, Gerber A, Häckel C, et al. Expression of cathepsin $\mathrm{K}$ in lung epithelial cells. Am J Respir Cell Mol Biol 1999; 20: 612-619.

29. Bühling F, Reisenauer A, Gerber A, et al. Cathepsin K - a marker of macrophage differentiation? J Pathol 2001; 195: 375-382.

30. Lemanski P, Brix K, Herzog V. Iodination of mature cathepsin D in thyrocytes as an indicator for its transport to the cell surfacs. Eur J Cell Biol 1998; 76: 53-62.

31. Pluger EB, Boes $\mathrm{M}$, Alfonso $\mathrm{C}$, et al. Specific role for cathepsin $\mathrm{S}$ in the generation of antigenic peptides in vivo. Eur J Immunol 2002; 32: 467-476.

32. Bania J, Gatti E, Lelouard H, et al. Human cathepsin S, but not cathepsin L, degrades efficiently MHC class II-associated invariant chain in nonprofessional APCs. Proc Natl Acad Sci USA 2003; 100: 6664-6669.

33. Wex T, Bühling F, Wex H, et al. Human cathepsin W, a cysteine protease predominantly expressed in NK cells, is mainly localized in the endoplasmic reticulum. J Immunol 2001; 167: 2172-2178.

34. Bühling F, Kellner U, Guenther D, et al. Characterization of novel anti-cathepsin $\mathrm{W}$ antibodies and cellular distribution of cathepsin W in the gastrointestinal tract. Biol Chem 2002; 383: $1277-1283$.

35. Linnevers C, Smeekens SP, Brömme D. Human cathepsin $\mathrm{W}$, a putative cysteine protease predominantly expressed in $\mathrm{CD}^{+}$T-lymphocytes. FEBS Letters 1997; 405: 253-259.

36. Chapman HAJ, Munger JS, Shi GP. The role of thiol proteases in tissue injury and remodeling. Am J Respir Crit Care Med 1994; 150: S155-S159.

37. Petanceska S, Canoll P, Devi LA. Expression of rat cathepsin S in phagocytic cells. J Biol Chem 1996; 271: 4403-4409.

38. Ebisui C, Tsujinaka T, Morimoto T, et al. Interleukin-6 induces proteolysis by activating intracellular proteases (cathepsins B and L, proteasome) in $\mathrm{C} 2 \mathrm{C} 12$ myotubes. Clin Sci 1995; 89: 431-439.

39. Li Q, Bever CTJ. Gamma interferon induced increases in intracellular cathepsin B activity in PMA primed THP-1 cells are blocked by inhibitors of protein kinase C. Immunopharmacol Immunotoxicol 1996; 18: 375-396.

40. Ling H, Vamvakas S, Busch G, et al. Suppressing role of transforming growth factor- $\beta 1$ on cathepsin activity in cultured kidney tubule cells. Am J Physiol 1995; 269: F911-F917.

41. Lugering N, Kucharzik T, Stein H, et al. IL-10 synergizes with IL-4 and IL-13 in inhibiting lysosomal enzyme secretion by human monocytes and lamina propria mononuclear cells from patients with inflammatory bowel disease. Dig Dis Sci 1998; 43: 706-714

42. Watari M, Watari H, Nachamkin I, Strauss JF. Lipopolysaccharide induces expression of genes encoding proinflammatory cytokines and the elastin-degrading enzyme, cathepsin S, in human cervical smooth-muscle cells. $J$ Soc Gynecol Investig 2000; 7: 190-198.
43. Li Q, Falkler WAJ, Bever CTJ. Endotoxin induces increased intracellular cathepsin B activity in THP-1 cells. Immunopharmacol Immunotoxicol 1997; 19: 215-237.

44. Mach L, Mort JS, Glossl J. Noncovalent complexes between the lysosomal proteinase cathepsin $\mathrm{B}$ and its propeptide account for stable, extracellular, high molecular mass forms of the enzyme. J Biol Chem 1994; 269: 13036-13040.

45. Billington CJ, Mason P, Magny MC, Mort JS. The slowbinding inhibition of cathepsin K by its propeptide. Biochem Biophys Res Commun 2000; 276: 924-929.

46. Maubach G, Schilling K, Rommerskirch W, et al. The inhibition of cathepsin S by its propeptide - specificity and mechanism of action. Eur J Biochem 1997; 250: 745-750.

47. Carmona E, Dufour É, Plouffe C, et al. Potency and selectivity of the cathepsin L propeptide as an inhibitor of cysteine proteases. Biochemistry 1996; 35: 8149-8157.

48. Guay J, Falgueyret JP, Ducret A, Percival MD, Mancini JA. Potency and selectivity of inhibition of cathepsin K, L and S by their respective propeptides. Eur J Biochem 2000; 267: 6311-6318.

49. Wittlin S, Rösel J, Stover DR. One-step purification of cathepsin D by affinity chromatography using immobilized propeptide sequences. Eur J Biochem 1998; 252: 530-536.

50. Dahl SW, Halkier T, Lauritzen C, et al. Human recombinant pro-dipeptidyl peptidase I (cathepsin C) can be activated by cathepsins $\mathrm{L}$ and $\mathrm{S}$ but not by autocatalytic processing. Biochemistry 2001; 40: 1671-1678.

51. Turk B, Turk D, Turk V. Lysosomal cysteine proteases: more than scavengers. Biochim Biophys Acta 2000; 1477: 98 111 .

52. Honey K, Duff M, Beers C, et al. Cathepsin S regulates the expression of cathepsin $\mathrm{L}$ and the turnover of gammainterferon-inducible lysosomal thiol reductase in B lymphocytes. J Biol Chem 2001; 276: 22573-22578.

53. Samarel AM, Ferguson AG, Decker RS, Lesch M. Effects of cysteine protease inhibitors on rabbit cathepsin D maturation. Am J Physiol 1989; 257: C1069-C1079.

54. Kirschke H, Wiederanders B. Cathepsin S and related lysosomal endopeptidases. Methods Enzymol 1994; 244 : 500-511.

55. Bromme D, Li ZQ, Barnes M, Mehler E. Human cathepsin $\mathrm{V}$ functional expression, tissue distribution, electrostatic surface potential, enzymatic characterization, and chromosomal localization. Biochemistry 1999; 38: 2377-2385.

56. Lennon-Dumenil AM, Roberts RA, Valentijn K, et al. The p41 isoform of invariant chain is a chaperone for cathepsin L. EMBO J 2001; 20: 4055-4064.

57. Mort JS, Recklies AD, Poole AR. Extracellular presence of the lysosomal proteinase cathepsin B in rheumatoid synovium and its activity at neutral pH. Arthritis Rheum 1984; 27 : 509-515.

58. Ni J, Fernandez MA, Danielsson L, et al. Cystatin F is a glycosylated human low molecular weight cysteine proteinase inhibitor. J Biol Chem 1998; 273: 24797-24804.

59. Lennon-Dumenil AM, Bakker AH, Maehr R, et al. Analysis of protease activity in live antigen-presenting cells shows regulation of the phagosomal proteolytic contents during dendritic cell activation. $J$ Exp Med 2002; 196: 529-540.

60. Schick C, Brömme D, Bartuski AJ, Uemura Y, Schechter NM, Silverman GA. The reactive site loop of the serpin SCCA1 is essential for cysteine proteinase inhibition. Proc Natl Acad Sci USA 1998; 95: 13465-13470.

61. Levicar N, Strojnik T, Kos J, Dewey RA, Pilkington GJ, Lah TT. Lysosomal enzymes, cathepsins in brain tumour invasion. $J$ Neurooncol 2002; 58: 21-32.

62. Adkison AM, Raptis SZ, Kelley DG, Pham CT. Dipeptidyl peptidase I activates neutrophil-derived serine proteases and regulates the development of acute experimental arthritis. $J$ Clin Invest 2002; 109: 363-371.

63. Halangk W, Lerch MM, Brandt-Nedelev B, et al. Role of cathepsin B in intracellular trypsinogen activation and the onset of acute pancreatitis. J Clin Invest 2000; 106: 773-781. 
64. Roth W, Deussing J, Botchkarev VA, et al. Cathepsin L deficiency as molecular defect of furless: hyperproliferation of keratinocytes and pertubation of hair follicle cycling. FASEB J 2000; 14: 2075-2086.

65. Hetman M, Perschl A, Saftig P, Von Figura K, Peters C. Mouse cathepsin D gene: molecular organization, characterization of the promoter, and chromosomal localization. DNA Cell Biol 1994; 13: 419-427.

66. Shi GP, Villadangos JA, Dranoff G, et al. Cathepsin S required for normal $\mathrm{MHC}$ class II peptide loading and germinal center development. Immunity 1999; 10: 197-206.

67. Saftig $\mathrm{P}$, Hunziker $\mathrm{E}$, Wehmeyer $\mathrm{O}$, et al. Impaired osteoclastic bone resorption leads to osteopetrosis in cathepsin-K-deficient mice. Proc Natl Acad Sci USA 1998; 95: 13453-13458.

68. Tsukuba T, Yamamoto K. Atopic dermatitis and cathepsin E. Nippon Yakurigaku Zasshi 2003; 122: 15-20.

69. Saftig P, Hetman M, Schmahl W, et al. Mice deficient for the lysosomal proteinase cathepsin D exhibit progressive atrophy of the intestinal mucosa and profound destruction of lymphoid cells. EMBO J 1995; 14: 3599-3608.

70. Deussing J, Roth W, Saftig P, Peters C, Ploegh HL, Villadangos JA. Cathepsins B and D are dispensable for major histocompatibility complex class II-mediated antigen presentation. Proc Natl Acad Sci USA 1998; 95: 4516-4521.

71. Friedrichs B, Tepel C, Reinheckel T, et al. Thyroid functions of mouse cathepsins B, K, and L. J Clin Invest 2003; 111: 1733-1745.

72. Canbay A, Guicciardi ME, Higuchi H, et al. Cathepsin B inactivation attenuates hepatic injury and fibrosis during cholestasis. J Clin Invest 2003; 112: 152-159.

73. Pham CT, Ley TJ. Dipeptidyl peptidase I is required for the processing and activation of granzymes $\mathrm{A}$ and $\mathrm{B}$ in vivo. Proc Natl Acad Sci USA 1999; 96: 8627-8632.

74. Belaaouaj A, McCarthy R, Baumann M, et al. Mice lacking neutrophil elastase reveal impaired host defense against Gram negative bacterial sepsis. Nat Med 1998; 4: 615-618.

75. Belaaouaj A, Kim KS, Shapiro SD. Degradation of outer membrane protein A in Escherichia coli killing by neutrophil elastase. Science 2000; 289: 1185-1188.

76. Wolters PJ, Pham CT, Muilenburg DJ, Ley TJ, Caughey GH. Dipeptidyl peptidase I is essential for activation of mast cell chymases, but not tryptases, in mice. J Biol Chem 2001; 276: 18551-18556.

77. Kiviranta R, Morko J, Uusitalo H, Aro HT, Vuorio E, Rantakokko J. Accelerated turnover of metaphyseal trabecular bone in mice overexpressing cathepsin K. $J$ Bone Miner Res 2001; 16: 1444-1452.

78. Benavides F, Venables A, Poetschke KH, et al. The CD4 $\mathrm{T}$ cell-deficient mouse mutation nackt (nkt) involves a deletion in the cathepsin L (CtsI) gene. Immunogenetics 2001; 53: 233-242.

79. Benavides F, Starost MF, Flores M, Gimenez-Conti IB, Guenet JL, Conti CJ. Impaired hair follicle morphogenesis and cycling with abnormal epidermal differentiation in nackt mice, a cathepsin L-deficient mutation. Am J Pathol 2002; 161: 693-703.

80. Stypmann J, Glaser K, Roth W, et al. Dilated cardiomyopathy in mice deficient for the lysosomal cysteine peptidase cathepsin L. Proc Natl Acad Sci USA 2002; 99: 6234-6239.

81. Yasothornsrikul S, Greenbaum D, Medzihradszky KF, et al. Cathepsin L in secretory vesicles functions as a prohormoneprocessing enzyme for production of the enkephalin peptide neurotransmitter. Proc Natl Acad Sci USA 2003; 100: 95909595.

82. Nakagawa T, Roth W, Wong P, et al. Cathepsin L: critical role in Ii degradation and CD4 $\mathrm{T}$ cell selection in the thymus. Science 1998; 280: 450-453.

83. Honey K, Nakagawa T, Peters C, Rudensky A. Cathepsin L regulates $\mathrm{CD} 4+\mathrm{T}$ cell selection independently of its effect on invariant chain: a role in the generation of positively selecting peptide ligands. $J$ Exp Med 2002; 195: 1349-1358.
84. Shi GP, Bryant RA, Riese R, et al. Role for cathepsin F in invariant chain processing and major histocompatibility complex class II peptide loading by macrophages. J Exp Med 2000; 191: 1177-1186.

85. Adachi W, Kawamoto S, Ohno I, et al. Isolation and characterization of human cathepsin V: a major proteinase in corneal epithelium. Invest Ophthalmol Vis Sci 1998; 39: 17891796.

86. Davidson JM. Biochemistry and turnover of lung interstitium. Eur Respir J 1990; 3: 1048-1063.

87. Punturieri A, Filippov S, Allen E, et al. Regulation of elastinolytic cysteine proteinase activity in normal and cathepsin K-deficient human macrophages. J Exp Med 2000; 192: 789-800.

88. Wolters PJ, Raymond WW, Blount JL, Caughey GH. Regulated expression, processing, and secretion of dog mast cell dipeptidyl peptidase I. J Biol Chem 1998; 273: 15514-15520.

89. Sukhova GK, Shi GP, Simon DI, Chapman HA, Libby P. Expression of the elastolytic cathepsins $\mathrm{S}$ and $\mathrm{K}$ in human atheroma and regulation of their production in smooth muscle cells. J Clin Invest 1998; 102: 576-583.

90. Heidtmann HH, Salge U, Abrahamson M, et al. Cathepsin B and cysteine proteinase inhibitors in human lung cancer cell lines. Clin Exp Metastasis 1997; 15: 368-381.

91. Frosch BA, Berquin I, Emmertbuck MR, Moin K, Sloane $\mathrm{BF}$. Molecular regulation, membrane association and secretion of tumor cathepsin B. APMIS 1999; 107: 28-37.

92. Heidtmann HH, Salge U, Havemann K, Kirschke H, Wiederanders B. Secretion of a latent, acid activatable cathepsin L precursor by human non-small cell lung cancer cell lines. Oncol Res 1993; 5: 441-451.

93. Röcken C, Stix B, Brömme D, Ansorge S, Roessner A, Bühling F. A putative role for cathepsin $\mathrm{K}$ in degradation of AA and AL amyloidosis. Am J Pathol 2001; 158: 1029-1038.

94. Lazner F, Gowen M, Pavasovic D, Kola I. Osteopetrosis and osteoporosis: two sides of the same coin. Hum Mol Genet 1999; 8: 1839-1846.

95. Diaz A, Willis AC, Sim RB. Expression of the proteinase specialized in bone resorption, cathepsin $\mathrm{K}$, in granulomatous inflammation. Mol Med 2000; 6: 648-659.

96. Lesser M, Padilla ML, Cardozo C. Induction of emphysema in hamsters by intratracheal instillation of cathepsin B. Am Rev Respir Dis 1992; 145: 661-668.

97. Stockley RA. Proteases and antiproteases. Novartis Found Symp 2001; 234: 189-199.

98. Barnes PJ. Potential novel therapies for chronic obstructive pulmonary disease. Novartis Found Symp 2001; 234: 255-267.

99. Takahashi H, Ishidoh K, Muno D, et al. Cathepsin L activity is increased in alveolar macrophages and bronchoalveolar lavage fluid of smokers. Am Rev Respir Dis 1993; 147: 15621568.

100. Wang Z, Zheng $\mathrm{T}, \mathrm{Zhu} \mathrm{Z}$, et al. Interferon gamma induction of pulmonary emphysema in the adult murine lung. $J$ Exp Med 2000; 192: 1587-1600.

101. Zheng T, Zhu Z, Wang Z, et al. Inducible targeting of IL-13 to the adult lung causes matrix metalloproteinase- and cathepsin-dependent emphysema. J Clin Invest 2000; 106: 1081-1093.

102. Weber E, Gunther D, Laube F, Wiederanders B, Kirschke H. Hybridoma cells producing antibodies to cathepsin L have greatly reduced potential for tumour growth. $J$ Cancer Res Clin Oncol 1994; 120: 564-567.

103. Krueger S, Kellner U, Buehling F, Roessner A. Cathepsin L antisense oligonucleotides in a human osteosarcoma cell line: effects on the invasive phenotype. Cancer Gene Ther 2001; 8: 522-528.

104. Krueger S, Haeckel C, Buehling F, Roessner A. Inhibitory effects of antisense cathepsin B cDNA transfection on invasion and motility in a human osteosarcoma cell line. Cancer Res 1999; 59: 6010-6014.

105. Demchik LL, Sameni M, Nelson K, Mikkelsen T, Sloane 
BF. Cathepsin B and glioma invasion. Int $J$ Dev Neurosci 1999; 17: 483-494.

106. Bühling F, Waldburg N, Gerber A, et al. Cathepsin $\mathrm{K}$ expression in human lung. Adv Exp Med Biol 2000; 477: 281286.

107. Batenburg JJ, Haagsman HP. The lipids of pulmonary surfactant: dynamics and interactions with proteins. Prog Lipid Res 1998; 37: 235-276.

108. Clark JC, Wert SE, Bachurski CJ, et al. Targeted disruption of the surfactant protein B gene disrupts surfactant homeostasis, causing respiratory failure in newborn mice. Proc Natl Acad Sci USA 1995; 92: 7794-7798.

109. Clark JC, Weaver TE, Iwamoto HS, et al. Decreased lung compliance and air trapping in heterozygous SP-B- deficient mice. Am J Respir Cell Mol Biol 1997; 16: 46-52.

110. Tokieda K, Whitsett JA, Clark JC, et al. Pulmonary dysfunction in neonatal SP-B-deficient mice. Am J Physiol 1997; 273: L875-L882.

111. Whitsett JA, Nogee LM, Weaver TE, Horowitz AD. Human surfactant protein B: structure, function, regulation, and genetic disease. Physiol Rev 1995; 75: 749-757.

112. Nogee LM, Dunbar AE III, Wert SE, Askin F, Hamvas A, Whitsett JA. A mutation in the surfactant protein $\mathrm{C}$ gene associated with familial interstitial lung disease. $N$ Engl $J$ Med 2001; 344: 573-579.

113. Nogee LM. Abnormal expression of surfactant protein $\mathrm{C}$ and lung disease. Am J Respir Cell Mol Biol 2002; 26: 641644.

114. Glasser SW, Detmer EA, Ikegami M, Na CL, Stahlman MT, Whitsett JA. Pneumonitis and emphysema in SP-C gene targeted mice. J Biol Chem 2003; 278: 14291-14296.

115. Weaver TE, Whitsett JA. Processing of hydrophobic pulmonary surfactant protein $\mathrm{B}$ in rat type II cells. $\mathrm{Am}$ J Physiol 1989; 257: L100-L108.

116. Voorhout WF, Veenendaal T, Haagsman HP, et al. Intracellular processing of pulmonary surfactant protein $\mathrm{B}$ in an endosomal/lysosomal compartment. Am J Physiol 1992; 263: L479-L486.

117. Voorhout WF, Weaver TE, Haagsman HP, Geuze HJ, van Golde LM. Biosynthetic routing of pulmonary surfactant proteins in alveolar type II cells. Microsc Res Tech 1993; 26: $366-373$.

118. Vorbroker DK, Voorhout WF, Weaver TE, Whitsett JA. Posttranslational processing of surfactant protein $\mathrm{C}$ in rat type II cells. Am J Physiol 1995; 269: L727-L733.

119. Guttentag SH, Beers MF, Bieler BM, Ballard PL. Surfactant protein B processing in human fetal lung. Am J Physiol 1998; 275: L559-L566.

120. Korimilli A, Gonzales LW, Guttentag SH. Intracellular localization of processing events in human surfactant protein B biosynthesis. J Biol Chem 2000; 275: 8672-8679.

121. Weaver TE, Lin S, Bogucki B, Dey C. Processing of surfactant protein B proprotein by a cathepsin D-like protease. Am J Physiol 1992; 263: L95-L103.

122. Arbustini E, Morbini P, Diegoli M, et al. Coexpression of aspartic proteinases and human leukocyte antigen-DR in human transplanted lung. Am J Pathol 1994; 145: 310-321.

123. Ishii Y, Hashizume Y, Kominami E, Uchiyama Y. Changes in immunoreactivity for cathepsin $\mathrm{H}$ in rat type II alveolar epithelial cells and its proteolytic activity in bronchoalveolar lavage fluid over 24 hours. Anat Rec 1991; 230: 519-523.

124. Ishii $\mathrm{Y}$, Hashizume $\mathrm{Y}$, Watanabe $\mathrm{T}$, et al. Cysteine proteinases in bronchoalveolar epithelial cells and lavage fluid of rat lung. J Histochem Cytochem 1991; 39: 461-468.

125. Guttentag S, Robinson L, Zhang P, Brasch F, Buhling F, Beers M. Cysteine protease activity is required for surfactant protein B processing and lamellar body genesis. Am J Respir Cell Mol Biol 2003; 28: 69-79.

126. Brasch F, ten Brinke A, Johnen G, et al. Involvement of cathepsin $\mathrm{H}$ in the processing of the hydrophobic surfactantassociated protein $\mathrm{C}$ in type II pneumocytes. Am J Respir Cell Mol Biol 2002; 26: 659-670. 